\title{
The Effect of Customer Satisfaction on Customer Loyalty in Kartu As Products in Makassar City Muhammad Ilham Wardhana Haeruddin ${ }^{1}$, M. Ikhwan Maulana Haeruddin ${ }^{2}$ \\ 1,2, Universitas Negeri Makassar \\ Email: ilham.wardhana@unm.ac.id
}

(Received: August 2020; revised: October 2020; published: October 2020)

\begin{abstract}
Competition is something that cannot be avoided .This study aims to determine the influence of customer satisfaction on customer loyalty in Kartu As products in Makassar City. This research was conducted in Makassar City with 105 respondents. The sampling technique used stratified random sampling. This study was analyzed using hypothesis testing with multiple regression analysis with the help of the SPSS 21 computer program, to perform the f-test, t-test, and the calculation of $\mathrm{R}$ square ( $\mathrm{r} 2$ ). The results of the analysis show that simultaneously the $\mathrm{X}$ variable (overall customer satisfaction, customer satisfaction dimensions, confirmation of expectations, re-purchase interest, willingness to recommend and customer dissatisfaction) has a significant effect on customer loyalty. In the t-test, there are two subvariables $\mathrm{X}$ that are not significant because the value of $t$ count $<t$ table, namely the dimensions of customer satisfaction (X2), and willingness to recommend (X5). From the calculation of R square (r2) of 0.423 , it shows that the percentage of the influence of variable $\mathrm{X}$ on variable $\mathrm{Y}$ is $42.3 \%$.
\end{abstract}

Keywords: Customer satisfaction; customer loyalty, products

\section{INTRODUCTION}

The relational approach is more concerned with relationships with individuals than relationships with social society. The reason is that so far marketing has only thought about how to sell a product and get a high level of sales, as well as how to get as many customers as possible. In other words, after the product is sold and the company gets new customers, at that time the relationship with the customer is complete, the customer has not been properly maintained and there has been no optimal effort so that the customer remains loyal to the company. The relational approach is a very efficient business for companies because finding new customers will be more expensive than building customer loyalty, and also because of (Stauss, cited by Hurriyati, 2008: 127) "the fact that the profitability of the company is directly proportional to the growth of the relationship between companies. and subscribers permanently".

With a relational approach, marketing must find ways to make customers stay loyal to the company for a long time, and the key is customer satisfaction. Loyalty is the emotion of customers coming to them, even though there are other, more financially profitable offers on the market. This is the main difference from satisfaction - loyalty is not a rational evaluation, but the result of several factors, which are often felt unconsciously (Kisivela et al., 2016).

In the global market, competition is something that cannot be avoided. The company will continue to look for ways not to be left out, therefore to win the competition and continue to survive in it, the company must be able to provide satisfaction to its customers. Consumer satisfaction or dissatisfaction with a product lies in the relationship between consumer 


\section{Jurnal Administrare: Jurnal Pemikiran Ilmiah dan Pendidikan Administrasi Perkantoran Volume 7 Number 2 July- December 2020. Pages 227-234}

expectations and the perceived performance of the product. Kotler \& Keller (2008) stated that if the product meets expectations, the consumer is satisfied. If the product does not meet expectations, the consumer is dissatisfied. If it exceeds expectations, consumers are very satisfied. Engel et al. (1995) states that satisfaction is defined here as a post-consumption evaluation that a chosen alternative at last meets or exceeds expectations. The satisfaction obtained by consumers is their evaluation of product performance when what they consume meets or exceeds initial expectations (Umar, 2003). Satisfaction does not only talk about assessment but also talks about the emotional attitudes and feelings that consumers give after consumption (Ningsih \& Segoro, 2014). Customer satisfaction is the key to building profitable relationships with consumers, to maintaining and growing consumers and maintaining their loyalty to the company. Loyalty of customers, employees and partners is related and related to each other (Dymshits, 2007)

In a decision process, consumers will not stop at the consumption process. Consumers will carry out an evaluation process of the consumption they have done. This is what is called an evaluation of post-purchase or post-consumption alternatives. The result of this process is that consumers are satisfied or dissatisfied with the product or service, the consumer will have a feeling of satisfaction or dissatisfaction with the consumption of the product or brand that he has done. Satisfaction allows consumers to buy and re-consume the product or service. Conversely, feeling dissatisfied allows consumers to be disappointed and stop repurchasing and consuming the product or service.

If customers are satisfied, they are likely to buy / use the product again (Lu et al., 2012) tell other people pleasant things about the product (Brown et al, 2005), pay less attention to the brand, and the competitor's advertising, let alone move to another company. For this reason, the company must immediately make measurements of the level of customer satisfaction on a regular basis, in order to know which attributes can satisfy customers and which are not. The company must establish a system that can handle any customer complaints. In this way, companies can learn how well they are performing and how to improve that performance and how to maintain good relationships with customers (Raassens \& Haans, 2017).

Satisfaction has a direct influence on loyalty (Caruana, 2002; Ho, Hsieh \& Yu, 2014; Martınez \& Rodriguez del Bosque, 2013). Consumer satisfaction leads to consumer retention, and affects purchase intention (Irshad et al., 2017). Therefore, an increase in the level of satisfaction will lead to an increase in the volume of purchases and recommendations of goods or services to other potential consumers which of course will have a long-term effect on the sustainable profitability expected by the company (Greenwell et al., 2002; Liu and Jang, 2009). This is considered capable of increasing customer loyalty (Haeruddin, 2018).

Loyalty is a positive attitude and a consumer's attachment which is based on the feeling of liking / liking the brand, feeling familiar with the brand and having pride in being a user of a particular brand and consumers buying that brand consistently, which can be seen from the commitment of consumers to keep using it. the brand. The higher the satisfaction and loyalty of consumers towards the company, the more competitive and profitable the company is (Frances $\&$ Tomas, 2019). By creating customer loyalty, a sustainable competitive advantage is born that will greatly help the company in a very competitive and dynamic environment (Lee and Cunningham, 2001; Leninkumar, 2017). 


\section{METHOD}

This research is employing quantitative approach by using two variables: Consumer Satisfaction and Customer Loyalty. This research was conducted in Makassar City where the population used in this study amounted to 1.5 million people and with the sampling method using Stratified Random Sampling, 105 samples were obtained, all of which were users of Kartu As. The samples were obtained from 6 strata based on the sub-districts in Makassar City.

Table 1.

Determination of Sample Fraction Value

\begin{tabular}{lccl}
\hline Sub District & Strata $\left(\mathrm{L}_{\mathrm{i}}\right)$ & $\mathrm{N}_{\mathrm{i}}$ & $\mathrm{f}_{\mathrm{i}}$ \\
\hline Makassar & $\mathrm{I}$ & 416 & 0,264 \\
Bontoala & II & 510 & 0,324 \\
Mariso & III & 444 & 0,282 \\
Wajo & IV & 76 & 0,048 \\
Tamalanrea & V & 74 & 0,047 \\
Ujung Tanah & VI & 56 & 0,036 \\
\hline
\end{tabular}

Based on the tabulated data above, each sample taken from the sub-population can be calculated as follows (the results have been rounded) : $\mathrm{n} 1=0,264 \times 105=28, \mathrm{n} 2=0,324 \times 105$ $=33, \mathrm{n} 3=0,282 \times 105=30, \mathrm{n} 4=0,048 \times 105=5, \mathrm{n} 5=0,047 \times 105=5, \mathrm{n} 6=0,036 \times 105=4$.

In analyzing the data, analytic test tools were used, including multiple regression analysis to look for relationships between variables (Astivia \& Zumbo, 2019; Seva et al, 2010)

\section{RESULT AND DISCUSSION}

To test the existing hypothesis, the $\mathrm{t}$ test is used to test the effect of each variable $\mathrm{X}$ on variable $\mathrm{Y}$ and test $\mathrm{f}$ to test the effect of variable $\mathrm{X}$ as a whole on variable $\mathrm{Y}$.

\section{T Test}

This test is used to determine whether in the regression model the independent variables $(\mathrm{X} 1, \mathrm{X} 2, \mathrm{X} 3, \mathrm{X} 4, \mathrm{X} 5)$ partially have a significant effect on the dependent variable (Y). The results obtained can be seen in the following table:

Table. 2

\section{T Test Results}

\begin{tabular}{|c|c|c|c|c|c|c|c|}
\hline & \multirow[b]{2}{*}{ Model } & \multicolumn{3}{|c|}{ Unstandardized Coefficients } & \multirow{2}{*}{$\begin{array}{c}\begin{array}{c}\text { Standardized } \\
\text { Coefficients }\end{array} \\
\text { Beta }\end{array}$} & \multirow[t]{2}{*}{$\mathrm{t}$} & \multirow[t]{2}{*}{ Sig. } \\
\hline & & B & & Std. Error & & & \\
\hline \multirow[t]{7}{*}{1} & (Constant) & & -.564 & 1.374 & & -.410 & .682 \\
\hline & $\mathrm{x} 1$ & & .134 & .052 & .209 & 2.567 & .012 \\
\hline & $\mathrm{x} 2$ & & -.022 & .044 & -.040 & -.494 & .623 \\
\hline & $\mathrm{x} 3$ & & .118 & .058 & .174 & 2.021 & .046 \\
\hline & $\mathrm{x} 4$ & & .394 & .103 & .380 & 3.833 & .000 \\
\hline & $\mathrm{x} 5$ & & .059 & .048 & .112 & 1.245 & .216 \\
\hline & x6 & & .129 & .060 & .169 & 2.155 & .034 \\
\hline
\end{tabular}




\section{Jurnal Administrare: Jurnal Pemikiran Ilmiah dan Pendidikan Administrasi Perkantoran Volume 7 Number 2 July- December 2020. Pages 227-234}

Testing the regression coefficient of the overall customer satisfaction variable. The level of significance used $\alpha=5 \%$. Based on the table, the $t$ count is 2,567 . The $t$ distribution table is sought at $t(n-1) .(1-\alpha), t(104)$. (1- 0.05), so that the $t$ table is 1.65 . The value of $t$ count $>t$ table (2.567> 1.65) then H0 is rejected. Sig value. on the spss results of $0.012<0.05$ then $\mathrm{H} 0$ is rejected. Because the value of $t$ count $>t$ table and the value of sig. spss $<5 \%$ significance level, then $\mathrm{H} 0$ is rejected, meaning that partially there is a significant influence between overall customer satisfaction and customer loyalty.

Testing the regression coefficient of the variable dimensions of customer satisfaction. The level of significance used $\alpha=5 \%$. Based on the table obtained $t$ count of -0.494 . The $t$ distribution table is found in $\mathrm{t}(\mathrm{n}-1)$. (1- $\alpha), \mathrm{t}(104)$. (1- 0.05), so that the $\mathrm{t}$ table is 1.65 . The value of $t$ count $<t$ table $(-0.494<1.65)$ then $\mathrm{H} 0$ is accepted. Sig value. on the spss results of $0.623>0.05$ then $\mathrm{H} 0$ is accepted. Because the value of $\mathrm{t}$ count $<\mathrm{t}$ table and the value of sig. spss $>5 \%$ significance level, then $\mathrm{HO}$ is accepted, meaning that partially there is no significant influence between the dimensions of customer satisfaction and customer loyalty.

Testing the regression coefficient of the expectation confirmation variable The level of significance used $\alpha=5 \%$. Based on the table, it is obtained t count of 2.021. The $t$ distribution table is found in $t(n-1) .(1-\alpha), t(104)$. (1- 0.05), so that the $t$ table is 1.65 . The value of $t$ count $>$ $\mathrm{t}$ table (2.021> 1.65) then $\mathrm{H} 0$ is rejected. Sig value. on the SPSs results of $0.046<0.05$ then $\mathrm{H} 0$ is rejected. Because the value of $t$ count $>t$ table and the value of sig. spss $<5 \%$ significance level, then $\mathrm{H} 0$ is rejected, meaning that partially there is a significant influence between the confirmation of expectations and customer loyalty.

Testing the regression coefficient of the re-purchase interest variable. The level of significance used $\alpha=5 \%$. Based on the table, it is obtained t count of 2.021 . The $t$ distribution table is found in $\mathrm{t}(\mathrm{n}-1) .(1-\alpha), \mathrm{t}(104) .(1-0.05)$, so that the $\mathrm{t}$ table is 1.65 . The value of $\mathrm{t}$ count $>$ $\mathrm{t}$ table $(3,833>1.65)$ then $\mathrm{H} 0$ is rejected. Sig value. on the spss results of $0.000<0.05$ then $\mathrm{H} 0$ is rejected. Because the value of $t$ count $>t$ table and the value of sig. spss $<5 \%$ significance level, then $\mathrm{HO}$ is rejected, meaning that partially there is a significant influence between repurchase interest and customer loyalty. Testing the regression coefficient of the willingness to recommend variable. The level of significance used $\alpha=5 \%$. Based on the table, it is obtained $t$ count of 1.245. The $t$ distribution table is found in $t(n-1) .(1-\alpha), t(104)$. (1- 0.05), so that the $t$ table is 1.65 . The value of $t$ count $>t$ table $(1.245<1.65)$ then $\mathrm{H} 0$ is accepted. Sig value. on the spss results of $0.216>0.05$ then $\mathrm{H} 0$ is accepted. Because the value of $t$ count $<t$ table and the value of sig. spss > 5\% significance level, then $\mathrm{H} 0$ is accepted, meaning that partially there is no significant influence between willingness to recommend and customer loyalty.

Testing the regression coefficient of the customer dissatisfaction variable. The level of significance used $\alpha=5 \%$. Based on the table obtained $t$ count of 2.155 . The $t$ distribution table is found in $t(n-1) .(1-\alpha), t(104)$. (1- 0.05), so that the $t$ table is 1.65 . The value of $t$ count $>t$ table $(2.155>1.65)$ then HO is rejected. Sig value. on the results of SPSs of $0.034<0.05, \mathrm{H} 0$ is rejected. Because the value of $t$ count $>t$ table and the value of sig. spss $<5 \%$ significance level, then $\mathrm{HO}$ is rejected, meaning that partially there is a significant influence between customer dissatisfaction with customer loyalty.

Based on the $t$ test above, it can be seen that the independent variable that most influences the dependent variable (customer loyalty) is the interest in repurchasing, so it can be concluded that the high interest in repurchasing indicates the loyalty of Kartu As customers in Makassar City. 


\section{F Test}

This test is used to determine whether the independent variables (X1, X2, X3, X4, X5) together have a significant effect on the dependent variable $(\mathrm{Y})$, or to find out whether the regression model can be used to predict the dependent variable or not. The results of the $\mathrm{f}$ test can be seen in the following table:

Tabel. 3

F Test Results $\mathbf{f}$

\begin{tabular}{llrrrrr}
\hline \multirow{2}{*}{ Model } & \multicolumn{1}{l}{$\begin{array}{l}\text { Sum } \\
\end{array}$} & \multicolumn{1}{c}{ Squares } & df & Mean Square & F & Sig. \\
\hline 1 & Regression & 67.641 & 6 & 11.273 & 11.967 & $.000^{\mathrm{a}}$ \\
& Residual & 92.321 & 98 & .942 & & \\
\hline \multicolumn{2}{l}{ Total } & 159.962 & 104 & & & \\
\hline
\end{tabular}

Source: Research Data, Processed 2019

The level of significance used is $\alpha=5 \%$ or $\alpha=0.05$. Based on the table, it is obtained that F count is 11.273. By using a confidence level of $95 \%, \alpha=5 \%$, df $1=6$, df $2=98$, the results obtained for the $F$ table are 2.20. The value of $F$ count> F table $(11.273>2.20)$, then H0 is rejected. Hence, it can be concluded that if $\mathrm{HO}$ is rejected, it means that overall customer satisfaction, dimensions of customer satisfaction, confirmation of expectations, re-purchase interest, willingness to recommend, and customer dissatisfaction together have a significant effect on customer loyalty.

This study also found the magnitude of the influence of the independent variable on the dependent variable which can be seen from the coefficient of determination ( $R$ square) and can be seen in table 4 below.

Tabel. 4

Regression Coefficient Test Results

\begin{tabular}{crrrr}
\hline Model & $\mathrm{R}$ & $\mathrm{R}$ Square & $\begin{array}{c}\text { Adjusted R } \\
\text { Square }\end{array}$ & $\begin{array}{c}\text { Std. Error of the } \\
\text { Estimate }\end{array}$ \\
\hline 1 & $.650^{\mathrm{a}}$ & .423 & .388 & .971 \\
\hline
\end{tabular}

Source: Research Data, Processed 2019

Based on the table above, the $\mathrm{R}^{2}$ ( $\mathrm{R}$ square) number is 0.423 or $42.3 \%$. This shows that the strength or predictive ability of the dependent variable (customer loyalty) to the independent variable (overall customer satisfaction, customer satisfaction dimensions, confirmation of expectations, re-purchase interest, willingness to recommend, and customer dissatisfaction) is $42.3 \%$. While the rest, which is $57.7 \%$, is influenced by other variables which are not included in this study.

\section{Discussion}

Based on the results of the t test, it is found that the independent variable that has the 


\section{Jurnal Administrare: Jurnal Pemikiran Ilmiah dan Pendidikan Administrasi Perkantoran Volume 7 Number 2 July- December 2020. Pages 227-234}

most influence on the dependent variable (customer loyalty) is the interest in repurchasing, so it can be concluded that the high interest in repurchasing indicates the loyalty of Kartu As customers in Makassar City. This shows that some respondents agree and have high interest in continuing to use an ace card even though the card they own is damaged or lost (Musa et al., 2018). This indicates that the customer is loyal to the phone card he uses even though it has been lost, and also because they do not want to be cut off from communication with people who already know the telephone number (Haeruddin, 2017).

Based on the $\mathrm{f}$ test, it was found that together the variables of overall customer satisfaction, customer satisfaction dimensions, confirmation of expectations, re-purchase interest, willingness to recommend, and customer dissatisfaction together have a significant effect on customer loyalty. Based on the table, it is obtained that F count is 11.273. By using a confidence level of $95 \%, \alpha=5 \%$, df1 $=6, \mathrm{df} 2=98$, the results obtained for the F table are 2.20. $\mathrm{F}$ value count $>\mathrm{F}$ table $(11,273>2.20)$.

\section{CONCLUSION}

Based on the results of the research and discussion that has been stated, the following conclusions can be drawn: there is an effect of customer satisfaction on customer loyalty; partially the variables of overall customer satisfaction, confirmation of expectations, interest in repeat purchases, and customer dissatisfaction have a significant effect on customer loyalty. Meanwhile, the variable dimensions of customer satisfaction and willingness to recommend have no influence on customer loyalty; customer satisfaction is not always followed by customer loyalty; among several independent sub-variables (customer satisfaction), the one that most indicates the level of customer loyalty is the interest in repeat purchases.

\section{REFERENCES}

Astivia, Oscar L. Olvera., \& Zumbo, Bruno D. (2019). Heteroskedasticity in Multiple Regression Analysis: What it is, How to Detect it and How to Solve it with Applications in $R$ and SPSS. Practical Assessment, Research, and Evaluation. Volume 24, Article 1

Brown, T.J., Barry, T. E., Dacin, P.A. \& Gunst, R.F. (2005). Spreading the word investigating antecedents of consumer's positive word-of-mouth intentions and behaviors in a retailing context. Journal of the Academy of Marketing Science, 33(2), 123-138

Caruana, A. (2002). Service loyalty: the effects of service quality and the mediating role cf customer satisfaction. European Journal of Marketing, 36(7/8), 811-828.

Dymshits, M. (2007). Basics of loyalty: A fragment of the book "customer loyalty: Re-purchase arrangements". Marketer, 6, 35-39.

Engel, James F., Blackwell, Roger D., \& Miniard, Paul W. (1995). Perilaku Konsumen. Jakarta, Bina Rupa Aksara, Hal. 3.

Frances, David Servera. \& Tomas, Lidia Piqueras. (2019). The effects of corporate social responsibility on consumer loyalty through consumer perceived value. Economic ResearchEkonomska Istraživanja, 32:1, 66-84

Greenwell, T.C., Fink, J.S., Pastore, D.L., 2002. Assessing the influence of the physical sports facility on customer satisfaction within the context of the service experience. Sport Manag. Rev. 5 (2), 129-148. 
Haeruddin, M. I. M. (2017). Pengaruh Gaji dan Insentif terhadap Kinerja Karyawan dan Organisational Citizenship Behaviour (OCB) pada Hotel Grand Clarion di Kota Makassar. Jurnal Aplikasi Manajemen, Ekonomi dan Bisnis, 2(1), 11-21.

Haeruddin, M. I. M. (2018). Light My Fire: A Perspective on Strategic Talent Management. Management, 8(1), 35-39.

Ho, Y. C., Hsieh, M. J., \& Yu, A. P. (2014). Effects of Customer-value Perception and Anticipation on Relationship Quality and Customer Loyalty in Medical Tourism Services Industry. Information Technology Journal, 13(4), 652-660.

Hurriyati, Ratih. (2008). Bauran Pemasaran Dan Loyalitas Konsumen. Bandung: Penerbit Alfabeta

Irshad, A., Rahim, A., Khan, M. F., \& Khan, M. M. (2017). The impact of corporate social responsibility on customer satisfaction and customer loyalty, moderating effect of corporate image. City University Research Journal, 2017(1), 63-73.

Kisivela, Elena M., Nekrasova, Marina L., Mayorova, Marina A., Rudenko, Marina N., \& Kankhva, Vadim S. (2016). The Theory and Practice of Customer Loyalty Management and Customer Focus in the Enterprise Activity. International Review of Management and Marketing. 2016, 6(S6) 95-103.

Kotler, Philip \& Armstrong. (2008). Dasar-Dasar Pemasaran. Alih Bahasa oleh Alexander Sindoro dan Tim Mark Plus, Jilid 1, Edisi Kesembilan, Jakarta, PT. Indeks Gramedia.

Lee, M., \& Cunningham, L.F., 2001. A cost/benefit approach to understanding service loyalty. J. Serv. Mark. 15 (2), 113-130.

Leninkumar, Vithya. (2017). The Relationship between Customer Satisfaction and Customer Trust on Customer Loyalty. International Journal of Academic Research in Business and Social Sciences, Vol. 7, No. 4

Liu, Y., \& Jang, S., 2009. Perceptions of Chinese restaurants in the US: what affects customer satisfaction and behavioral intentions? Int. J. Hosp. Manag. 28 (3), 338-348.

Lu, Y., Lu, Y., \& Wang, B., (2012). "Effects of Dissatisfaction on Customer RepurchaseDecisions in E-commerce-An Emotion-Based Perspective". Journal of Electronic Commerce Research, Vol. 13, No. 3:224-237.

Martinez, P., \& Rodriguez del Bosque, I. (2013). CSR and customer loyalty: The roles of trust, customer identification with the company and satisfaction. International Journal of Hospitality Management, 35, 89-99. (December)

Musa, M. I., Haeruddin, M. I. W., \& Haeruddin, M. I. M. (2018). Customers' repurchase decision in the culinary industry: Do the Big-Five personality types matter? Journal of Business and Retail Management Research, 13(1).

Ningsih, Minarti., \& Segoro, W. (2014). The influence of customer satisfaction, switching cost and trusts in a brand on customer loyalty - the survey on student as im3 users in Depok, Indonesia. Procedia - Social and Behavioral Sciences, 143(August), 1015 - 1019

Raassens, Ne'omie \& Haans, Hans. (2017). NPS and Online WOM: Investigating the Relationship Between Customers' Promoter Scores and eWOM Behavior. Journal of Service Research. Vol. 20(3) 322-334.

Seva, Urbani Lorenzo., Ferrando, Pere J., \& Chico, Eliseo. (2010). Two SPSS programs for interpreting multiple regression results. Behavior Research Methods. 42 (1), 29-35.

Umar, Husein. 2003. Metode Riset Perilaku Konsumen Jasa. Jakarta : PT Ghalia Indonesia. 
234 Jurnal Administrare: Jurnal Pemikiran Ilmiah dan Pendidikan Administrasi Perkantoran Volume 7 Number 2 July- December 2020. Pages 227-234 